\title{
INFLUENCIA DE LA CÁTEDRA EXTENSIÓN RURALY ASIGNATURAS SOCIALES, EN EL PERFIL PROFESIONAL DEL EGRESADO DE LA FCA-UNL
}

\author{
Barbero, C. ${ }^{1}$; Capelino, P. ; Finello, M. ${ }^{1}$; \\ SanCheZ, S. ${ }^{1,2} ;$ SANDOVAl, P. ${ }^{1} ;$ \& Bulgarella, E. ${ }^{2}$
}

\begin{abstract}
RESUMEN
Se abordó la influencia de la asignatura Extensión Rural y por ende el valor de las asignaturas sociales, dentro de la formación del ingeniero agrónomo de la Facultad de Ciencias Agrarias- Universidad Nacional del Litoral (FCA-UNL) en el marco del plan de estudio vigente. La indagación se realizó a través de encuestas sobre todas las cohortes que se encontraban en la base de datos que dispone el Centro de Graduados. En los orígenes de la FCA el perfil profesional estuvo orientado hacia la importancia del componente social en la actividad agropecuaria. Con el correr del tiempo esta orientación obtuvo su formalización en el perfil profesional actual, en base a la creación de la cátedra de Extensión Rural y un eje del área social que recorre el curriculum desde el inicio hasta el final de la carrera.

Palabras claves: Egresados (UNL-FCA), Extensión Rural y Perfil profesional.
\end{abstract}

\section{SUMMARY}

Influence of the Rural Extension chair and social subjects, the professional profile of the graduate of the FCA-UNL

The influence of the subject Extension Rural and therefore it was discussed the value of social subjects, within the formation of the agronomist of the Facultad Ciencias Agrarias- Universidad Nacional of Litoral (FCA-UNL) in the framework of the existing curriculum. The inquiry was conducted through surveys on all cohorts encountered in the data base which provides Graduate Center. In the origins of the FCA professional profile was oriented towards the importance of the social component in the farming activity. With the passage of time this guidance was its formalization in current professional profile, based on the creation of the Chair of Rural outreach and an axis of the social area that runs along the curriculum since the beginning until the end of the Race.

Key words: graduates (UNL-FCA), Rural Extension and professional profile.

1.- Facultad de Ciencias Agrarias (UNL). Kreder 2805. (3080) Esperanza, provincia de Santa Fe. 2.- Observatorio Social de la Universidad Nacional del Litoral.

Manuscrito recibido el 23 de febrero de 2012 y aceptado para su publicación el 21 de junio de 2012. 